\title{
Will Bus Subsidy in Indonesia Sustainable?
}

\author{
Muhammad Nanang Prayudyanto, ${ }^{1, *}$, Muiz Thohir $^{2}$, and Stefan Belka ${ }^{3}$ \\ ${ }^{1}$ Lecturer of Civil Engineering, University of Ibn Khaldun (UIKA), Bogor, Indonesia, \\ ${ }^{2}$ Directorate of Planning and Development, Greater Jakarta Transport Authority (BPTJ) \\ ${ }^{3}$ GIZ German
}

\begin{abstract}
The subsidies for public transport entails a controversial discussion on the pros and cons. On one hand mode share of public transport will decrease with increasing income levels towards private motor vehicle use. Intention of this paper is to prove that subsidy plays important role in the public transport operation and business. However such subsidy is not recover he needs to carry out the sustainable urban transport in the future. Government and private partner should create a systematic subsidy targeted for the right modes, that having sustainable achievement. This paper is structured to answer to what extent the effectiveness of government subsidies for the development of public transport services.
\end{abstract}

Keywords: public transport, subsidy, transport services

\section{Introduction}

Urbanization and economic developments proceed very rapidly in Indonesia. With rising income and prosperity various problems appear. In the transport sector traffic congestion and environmental pollution has become a daily appearance and is not a problem of megacities anymore, but also affecting smaller cities. Urban quality of life decreases, caused by a disproportional high growth of private motor vehicles. It is estimated that the annual average growth rate of motorcycles and cars in Indonesia has accounted for $15 \%$ over the last three years. Traffic jams and accidents increase just as much as air and noise pollution from motor vehicles and worsening conditions for pedestrians and cyclists and for public transport pick up the pace.

One governmental instrument to improve the situation is subsidies for public transport. Generally, subsidy policies on public transport are implemented under two major premises. First, they may be motivated because of the "social function". Vulnerable groups such as low-income households, persons without a driver license, elderly and persons with a handicap (mentioned in Al Qur'an Surah Al Isra': 30)., need public transport to take part in daily routine and to avoid problems of social exclusion Second, public transport subsidies may be motivated as an instrument to increase the share of public transport and to address urban transport problems caused by private motor vehicle use. Like, depict above these problems are e.g. air pollution, noise or congestion. Subsidizing public transport may aim to

\footnotetext{
*Corresponding author: muhammadprayudyanto@gmail.com
} 
encourage a modal shift away from private motor vehicle use towards the utilization of more environmentally friendly modes like busses. Subsidies are provided, particularly in Indonesia, by central Governments in remote areas aiming e.g. to provide bus services with fares below market price on pioneer routes to ensure the junction and (economic) exchange between deprived and wealthy areas of the country.

Beneath these positive objectives, public transport subsidies in Indonesia often lacks incoherent and intransparent policies causing an inefficient allocation and application of public funds. Results are e.g. an economic unnecessary high stock of staff in public transport companies.

\subsection{Vehicles}

The number of vehicles continues to increase. Data on the number of vehicles in 2015 from the Greater Jakarta Transport Authority shows the total number of vehicles reached 24,897,391 [13] consisting of compositions 13\% private automobile, $23 \%$ bus, $56 \%$ motorcycles, $4 \%$ rail and $4 \%$ walk [6]. The ratio of the number of vehicles on the population the vehicle ratio to population is increasing dramatically to 801 vehicles per 1,000 population (2015) or triple for 10 years [14]. Judging from these parameters, the city including the cities with the highest rate of growth in the vehicle along with the cities of Tokyo, Taipei, Seoul, Manila, Shanghai, and Bangkok.

\subsection{Role of Public Transport}

Public transport is the backbone of the movement of urban transport. Metropolitan cities such as Jakarta, Surabaya, Bandung, Medan, and Makassar relying role to public transport for more than $20-30 \%$ of trips each day. Modes of transportation ranging from public transportation, BRT, regular buses, rail and even rickshaws and taxis and shuttles moving river transport accessibility between urban corners fast, easy and inexpensive.

\subsection{Theory of Subsidy}

A subsidy is a difference between the production costs of a good and revenues from sales to final users. Its aim is to restore profitability in the production of a good, in order to make it available in quantities and qualities otherwise not provided by the normal functioning of the market [6]. Therefore subsidization is deliberately performed by an agent in order to let some activities exist and grow. Good reasons for subsidizing public transit have been repeatedly suggested by economists. Standard arguments are economies of scale, secondbest problems, redistribution in kind, option value, imperfect information. For all these reasons it might be socially useful to sustain the production of public transit. But to what extent should we provide this support?

The cost-benefit analysis allows us to define subsidization rules on the basis of a welfare comparison between alternative uses of subsidies. The alternative uses are given by different combinations of adjustments in tariff and quality of transit service with respect to the initial situation. Therefore cost-benefit analysis identifies the adjustments in tariff and quality of service that maximizes social welfare given a budget constraint on the total amount of subsidy. The main difficulty in these calculations is the presence of a quality index both in the demand and cost functions1. Let $D(b, q)$ and $C(D(b, q), q$,$) be respectively$ the demand and the short-run cost function of transit, where $b$ is the tariff and $q$ is the quality index 2 . For any initial situation $\left(b_{0}, q_{0}\right)$ define the consumer surplus $S$, and the producer surplus $\mathrm{P}$, by: 


$$
\begin{aligned}
& S=\int_{b_{0}}^{\infty} D\left(v, q_{0}\right) d_{v} \\
& P=b_{0} D\left(b_{0}, q_{0}\right)-C\left(D\left(b_{0}, q_{0}\right), q_{0}\right)
\end{aligned}
$$

Given this initial situation $\left(b_{0}, q_{0}\right)$, it is possible to calculate the net benefit for each amount of money spent alternatively to lower the tariff or to improve the quality of service. In the first case, the net benefit per unit of subsidy will be given by the equation:

$$
\frac{d B_{b}}{d T_{b}}=\frac{\frac{\partial W}{\partial b}}{\frac{\partial P}{\partial b}}=\frac{-\left(b_{0}-C_{D}\right) \varepsilon_{b}}{b_{0}+\left(b_{0}-C_{D}\right) \varepsilon_{b}}
$$

where $\mathrm{dB}_{\mathrm{b}}$ is the net benefit due to a tariff reduction, measured by the variation in total surplus $\mathrm{W}=\mathrm{S}+\mathrm{P}, \mathrm{dT}_{\mathrm{b}}$ is the required increase in subsidy, given by the variation of producer surplus and $b$ represents tariff elasticity of transit demand. Equation (3) is quite easy to calculate since it is made of known ingredients: tariff, tariff elasticity of demand and the marginal cost of service.

\section{Subsidies in Public Transport}

According to the Law No. 22/2009, Indonesia has established a national transport policy on subsidies. Article 185 says that subsidies for public passenger transport (covering bus, rain and sea transport) can be given by the Government or the Local Government on particular routes with economic class fares. Subsidy provisions for any other aspects of public transport are specified and regulated by Government [7]. Based on this quite rough regulation a detailed regulation is currently drafted by the Ministry to detail the subsidy aspects [7].

Based on the laws and regulations in place subsidies for public transport is used in various ways.

\subsection{Fuel Consumption}

In Indonesia, public spending is much smaller on mass transit than on fuel subsidies. Fuel subsidies encourage driving, making Jakarta's, and many other cities', terrible traffic worse, and leave most stuck in traffic, relying on an underfunded transit system, and arriving late to school.

Road-based modes of land transportation are the largest consumer of the fuel needs of national [8]. Needs of the road sector movement consumes $88 \%$ of all fuel needs, while the rest is consumed by the air transport sector (4\%), marine transportation $(7 \%)$ and rail $(1 \%)$. Estimated future consumption trends roads sector will also remain dominant. The number of vehicle bus reached $3.35 \%$ of the population of vehicles but motorcycles skyrocketed reached $74.12 \%$. In the land transport sector, consumption of premium is $61.17 \%$ and diesel is $38.83 \%$.

Indonesia, and as nations such as Iran, India, China, Nigeria, Venezuela, Mexico, and the US, spends about 15 percent of its entire budget, USD $\$ 18.5$ billion, subsidizing fuel prices. That's more than Indonesia's government spends on infrastructure, the military, or public health and education together. This does not include the costs incurred by pollution, congestion, accidents, infrastructure, or the funding lost to more equitable transportation modes like bus rapid transit or cycling. 
According to the International Energy Agency, 37 nations in 2010 spent \$409 billion artificially lowering the price of fossil fuels. These massive subsidies boost oil and gas consumption and impede investment in more efficient, environmentally conscious and equitable modes, which benefit the poor. Only eight percent of fossil fuel subsidies go to the poorest 20 percent of the population, and ending fuel subsidies would promote efficiency as well as equity. The IEA estimates that phasing out fossil fuel subsidies alone would reduce carbon dioxide emissions by 4.7 percent by 2020 .

About Rp.120 trillion ( $\$ 9.6$ billion) will be reallocated to infrastructure, including irrigation, roads, ports, power plants, and welfare programs. In the document, the government outlined the infrastructure targets that can be achieved with the budget reallocation, including:

- The development of 2,650 kilometers of new roads, and 1,000 km of new toll roads

- 15 new airports, 20 new charter planes, and new airport developments for cargo planes in 6 locations

- 24 new ports, 26 new cargo ships, and 500 small boats for fishermen

- $\quad 3,258 \mathrm{~km}$ of railroads in Java, Sumatra, Sulawesi, and Kalimantan - 2,159 km of intercity railroads and 1,099 km of intracity railroads

- 29 new Bus Rapid Transit (BRT) systems, and build new public transportation in 6 metropolitan and 17 big cities

\subsection{Public Service Obligations (PSO)}

In general subsidies for public transport have been provided for land, air, and sea (including inter islands ferries) in Indonesia. Strategic transportation routes are often organized by private operators while outside these corridors and for pioneer routes, the government provides support in the form of public service obligations (PSO) in the rail and sea transport.

PSO is an arrangement in which a governing body or other authority offers an auction for subsidies, permit the winning company a monopoly to operate a specified service of public transport for a specified period of time for the given subsidy. This is done in cases where there is not enough revenue for routes to be profitable in a free market, but where there is a socially desirable advantage in this transport being available. For example, according to the decision of Director General of Civil Aviation's approximately 118 air transport routes (a pioneer in 14 provinces) have received air transport operating- and fuel subsidies. Every year the Ministry of Transport (MoT) evaluates the routes and determines the pioneer routes and which will become subsidized. Inland transport POS are not used but just called subsidies. In 2009 subsidies in the form of Public Service Obligation (PSO) was allocated for IDR 1.485 trillion (USD 166 million) for the sea (600million IDR) and rail (585 million IDR) sector.

\subsection{Import Duty Subsidies}

A fuel price hike and a decreasing value of the Indonesian exchange rate increased the costs for public transport operators. In addition, public transport tariffs are inflexible and set by the Government. Public transport operators are not able to react to price changes by adjusting their fares appropriately. For this reason, the Ministry of Finance passed a regulation in 2005 to disburden operators by granting import duty exemptions. These subsidies are appointed for specific types of spare parts, of buses, bus chassis and engines used for public transport [7]. 


\subsection{Urban Public Transport Subsidies}

Public road land transport is generally operated by governmental companies and private enterprises. Social sensitive routes like pioneer routes are run by state operators using subsidies to some extent where the operation is not economical cost-effective. Since the past six years a fleet of 340 buses used to serve a transport pioneer network of 128 routes in 21 provinces all over the country.

Others routes are served under market conditions by private companies and partly by governmental enterprises. A typical characteristic of private companies is that the services they provide suffer from a lack of quality however fares have remained affordable without subsidies. The following passages give a short overview of the situation.

\subsubsection{State-Owned Company}

DAMRI (Djawatan Angkoetan Motor Repoeblik Indonesia) is the state-owned bus operator in Indonesia. It was created on November 25, 1946, and operates under the mandate of the Ministry of Transportation. DAMRI operates urban bus services through subsidiaries in 14 of the largest cities in Indonesia. Its main task according to its statute is to provide transport services for people but the company is also expected to act as a "stabilizer" and "dynamizer" in the passenger transport sector.

It is subsidized for losses on pioneer routes. The company has exclusive rights to many urban trunk corridors but also operates within the city, on inter-city, inter-province and cross-country routes. Within most cities, DAMRI only operates a small number of busses, however often on cost-effective routes, for example, Jakarta City - Jakarta Airport, and is competing with other private public transport companies under market conditions.

\subsubsection{Private Companies}

Additionally to the government-owned company private operators serve the market. In General, the public bus transport sector suffers from an unrestricted access and a lack of regulation. This results in a very fragmented, intransparent market that is hard to monitor. Private operators are provided with route permits, issued by the Local Transport Bureau to operate for a certain period of time.

However, they are not obliged to provide a minimum service standard and they are not awarded (operational) subsidies (only for import duty subsidies). Tariff setting for economy class fares is done by the government based on vehicle operating costs. For business class services (e.g. trips with air conditioner) tariffs are based on market prices and private companies can set their own tariffs within an upper and lower level. To maximize their profits they often possess only a very low level of service quality with badly maintained buses and high passenger load making public transport very unattractive and amplify the use of private vehicles.
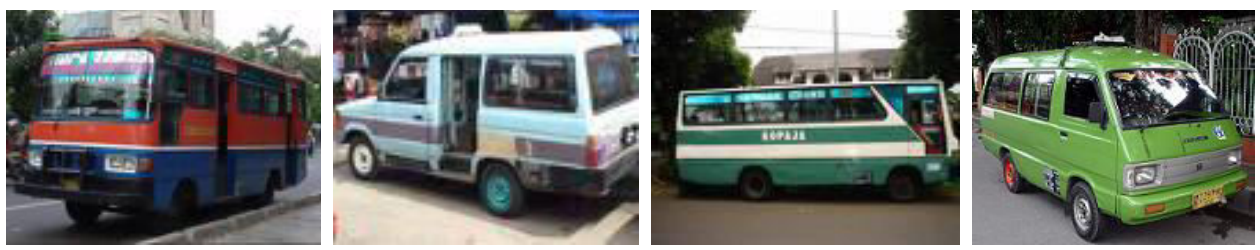

Fig. 1. Different types of public transport modes operated by private companies. 


\subsubsection{BRT-Trans Jakarta}

Indonesia implemented successfully the first full Bus Rapid Transit (BRT) System in Asia. The TransJakarta BRT system was started in February 2004 and is operated by the Public Service Agency (BLU) which is a part of the Jakarta local government transportation agency. The ticket price of IDR 3,500 (USD 38 cents) is subsidized by the local government so that it is affordable for the whole community. At the end of 2012, the number of subsidies was approximately 50 million USD [9]. BLU aims to stop subsidization until 2014. The management of Trans Jakarta Busway has estimated that the entity of the subsidy will be reduced until 2014 (figure 6). The efforts to reduce subsidy are by a) increasing tariff from 3,500 to 5,000 (about $\$ 0.5$ ) and b) increasing passenger demand from transport modal shift and natural population growth.

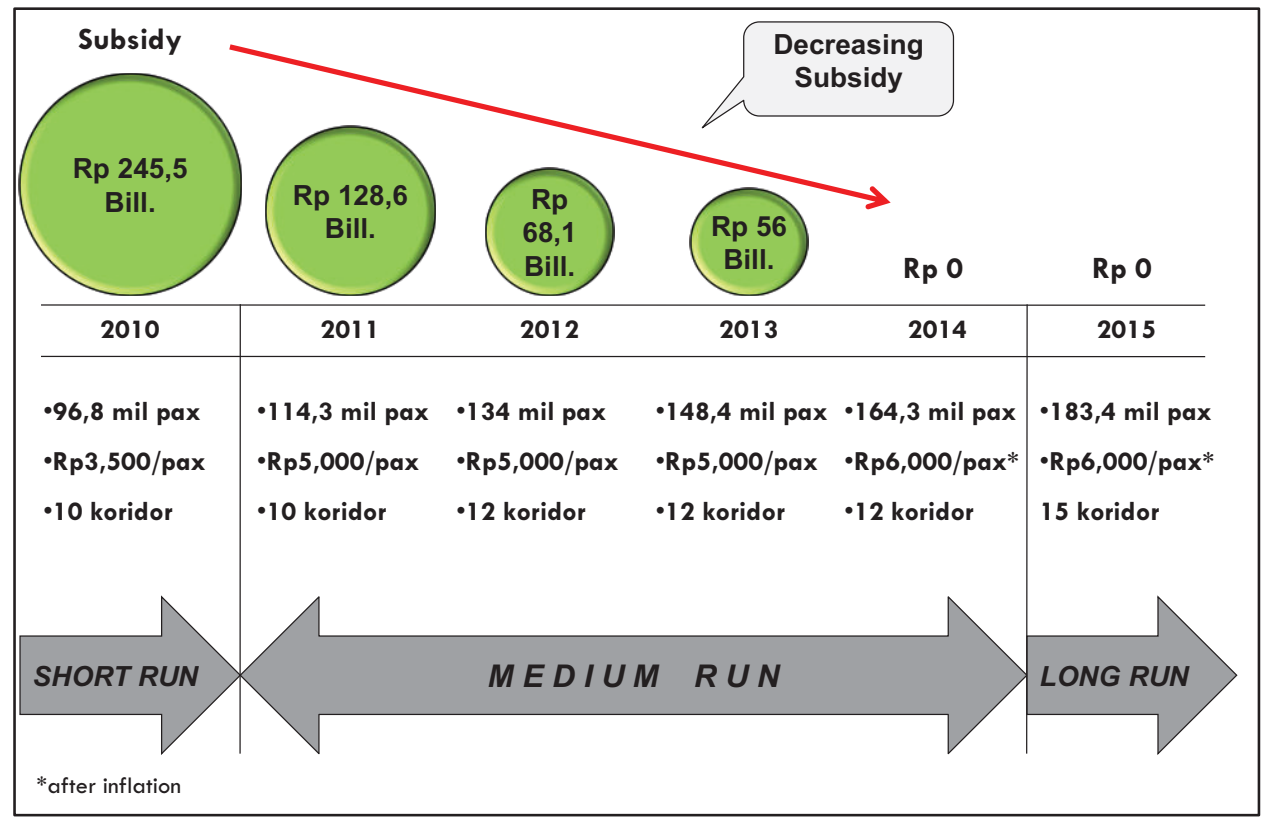

Fig. 2. The target of Subsidy by Trans Jakarta Busway

\subsubsection{BRT- in Greater Jakarta}

BRT Trans Jakarta has been developed in Greater Jakarta. (1) In 2010 APTB (Angkutan Perbatasan Terintegrasi Busway) to extend the Trans Jakarta BRT services, initiated by Dishub Jakarta. In March 2016 this APTB is no longer operating due to regulation matter. (2) Trans Jabodetabek BRT is launched in 2016 with an investment subsidy from Directorate General of Land Transport MoT from the national budget. 1,000 buses are operated by the national state-owned company, PT.PPD. (3) Operational subsidy under Provincial Government of Jakarta serves Trans Jabodetabek operation by PT.PPD.

\section{Discussion}

Subsidies dedicated to cover operational costs may be misused to a high extent (e.g. to finance an economic unnecessary high stock of staff) and may be allowed only under exceptional circumstances and for a limited period of time. This aims to avoid the 
inefficient and wasteful use of financial resources. Particularly in countries like Indonesia with high population densities and a high demand for public transport, it is possible to cover operational costs by fare revenues making operational subsidization unnecessary.

Concrete recommendations are:

- Define minimum service standards for privately operated public transport enterprises to increase standard and attractiveness of public transport

- Establish a transport authority responsible for the management of public funds to procure transport services, distribute subsidy and secure the best value for money. The authority supervises that / is responsible for:

- the provision of subsidies is allowed for the creation of public transport infrastructure and facilities

- Existing subsidies for operation will be abolished. This can be done by phasing out programs like aspired in the case of Jakarta`s TransJakarta BRT system

- Drafting, adopting and maintaining a coherent and realistic public transport policy, which is within the constraints of available resources, is fundamental to public transport planning and regulation. Subsidies require sophisticated administrative mechanisms to ensure they are allocated efficiently and agencies are accountable.

Therefore it is unavoidable to strengthen capacities responsible for urban (public) transport and public funds. Hence the following is recommended:

\subsection{Strengthened Urban Transport Institutions at the National and Local Government Levels}

Aimed at improving urban public transport services, what is needed is to strengthen the abilities of the Ministry too, first, advance urban passenger transport reforms, and second, advance best practices in urban public transport policy, planning, and engineering. Part of this capability is expected to develop within the Ministry, and part in educational institutions that could be contracted by the Ministry to conduct training programs for city officials in urban transport. It is also expected that, as a result of this approach, cities would attain an improved institutional ability and practical knowledge to plan, design, budget, and implement urban public transport services and urban transport infrastructure and traffic management on a sustainable basis.

\subsection{High Subsidy High Sustainability?}

Subsidizing users' fares for public transport may sound like a great idea, and often there are good economic reasons for doing so. In all industrialized and many developing countries, urban transport systems are subsidized with public funds in order to continue operating. It sounds even better if subsidies target certain populations, such as students, older adults, or low-income communities. For example, Bogota, Colombia gives subsidies to low-income individuals, people with disabilities, and seniors, and is planning to expand support to students, according to a draft ordinance recently approved by City Council [14].i this case Jakarta has not targeted type of public transport passenger subsidy but subsidy for the modes as a whole.

There are two important points to keep in mind about transit subsidies: 1) subsidizing users' fares, particularly with targeted subsidies, is effective; and 2) discounted fares for particular populations should not be funded by charging other passengers more. By 
focusing on both sides of the equation, city leaders can ensure an efficient and sustainable transport system

\subsection{Improved Quality and Financial Sustainability of Urban Public Transport Services}

This is to be achieved principally through implementing reforms in those cities that are willing to provide core urban public transport services on a well-managed, competitive basis. More specifically, for exclusive provision of urban public transport services on selected routes or sections of the participating city, under contracts of sufficient length to attract serious bidders.

Accompanied by all these recommendations it is necessary to phase out fuel subsidies. This has to be done in small steps over a period of several years to create a smooth switch to a higher share of public transport. This is particularly important for low and lowermiddle income groups who have to use up to $20 \%$ of their income for public transport. This is often the reason why many of them shift to motorcycles. Savings from fuel price subsidy reduction need to be redirected for the improvement of public transport systems.

\section{References}

1. The Holy Qur'an

2. Acharya, RA, and Morichi, S, Motorization, and Role of Mass Rapid Transit in East Asian Megacities, IATSS, Tokyo, (2007)

3. Belka, S., Prayudyanto, MN, Jinca, A., Public Transport Subsidy, GIZ-SUTIP Discussion Paper, Jakarta, (2010)

4. BMZ, Germany Federal Ministry for Economic Cooperation and Development, International Fuel Prices 2010/2011, Berlin, (2011)

5. Fabbri, D., "Public Transit Subsidy: From The Economics of Welfare to The Theory of Incentives", Department of Economics, University of Bologna, Italy (1995). https://core.ac.uk/download/pdf/143609332.pdf

6. JICA, "Jabotabek Public Transportation Policy Implementation Strategy (JAPTraPIS)”, http://open_jicareport.jica.go.jp/pdf/12079000_01.pdf, (2012)

7. Ministry of Finance, “Application of Fuel Tax vehicles by Law No. 28/2009 related to subsidized fuel”, Jakarta, (2010)

8. Ministry of Transportation, Anticipation of Fuel Price Increase, Jakarta, (2005)

9. Sinaga, E., Management Requirement (TDM) and Analysis Impact Then Traffic in Urban Areas, Mataram, (2011)

10. The government of Indonesia, Law 22/1999 on Road Traffic and Transport, Jakarta, (2010)

11. Directorate of Urban Transport System Development, Transit Forum-1, Jakarta, (2010)

12. Prayudyanto, et.all, "Draft Guidelines for Public Transport Subsidy in Jabotabek Area", GJTA, unpublished, (2017)

13. Prayudyanto, Jinca, Belka, Role of Urban Transport Subsidy in Indonesia, EASTS Proceeding, (2013) 
14. Hidalgo, D., "To Subsidize or Not to Subsidize Public Transport: That Is the Question", World Resources Institute, 2015 . http://thecityfix.com/blog/subsidizepublic-transport-that-is-the-question-dario-hidalgo/ 